J. Lake Sci. (湖泊科学), 2013, 25(5): 749-755

http: //www. jlakes. org. E-mail : jlakes@niglas.ac.cn

(c) 2013 by Journal of Lake Sciences

\title{
广东长潭水库富营养化与浮游植物分布特征"
}

\author{
王 超 ${ }^{1,2}$, 高越超 ${ }^{1,2}$, 王沛芳 ${ }^{1,2 * *}$, 张松贺 ${ }^{1,2}$, 侯 俊 ${ }^{1,2}$, 钱 进 ${ }^{1,2}$ \\ ( 1 : 河海大学浅水湖泊综合治理与资源开发教育部重点实验室,南京 210098) \\ $(2$ : 河海大学环境学院,南京 210098)
}

摘 要: 为掌握梅州市长潭水库富营养化状态与浮游植物分布特征, 为控制藻类水华暴发提供科学依据, 2011 年 10 月至 2012 年 7 月,在长潭水库关键断面选取 10 个监测点,测定水体理化特征、浮游植物种类、丰度等指标, 采用营养 状态指数 (TLI) 和 Shannon-Wiener 多样性指数法对水质污染现状进行评价, 并分析浮游植物类群分布特征. 结果表明: 长潭水库水体富营养状态在 $4 、 10$ 和 12 月处于中营养级, 7 月份处于富营养级, 营养指数从库区一中游一上游逐渐降 低; 观测期间共检出浮游植物 4 门 11 科 16 属, 通过丰度比较, 发现长潭水库以蓝一绿藻为优势种, 并且季节变化明显, 总体表现为 7 月 $>4$ 月 $>10$ 月 $>12$ 月; 藻类多样性指数分析显示, 水库水体污染水平为中度, 中游和库区 (除 7 月) 为 轻度污染,与综合营养指数结果一致;长潭水库污染源调查分析结果表明,该水库主要为氮、磷污染,污染源主要为上 游禽畜养殖废水.

关键词: 浮游植物; 富营养化; 长潭水库

\section{Eutrophication and characteristics of phytoplankton distributions in Changtan Reservoir, Guangdong Province}

\author{
WANG Chao $^{1,2}$, GAO Yuechao ${ }^{1,2}$, WANG Peifang ${ }^{1,2}$, ZHANG Songhe ${ }^{1,2}$, HOU Jun ${ }^{1,2}$ \& QIAN Jin ${ }^{1,2}$ \\ (1: Key Laboratory of Integrated Regulation and Resource Development on Shallow Lakes, Ministry of Education, Hohai Uni- \\ versity, Nanjing 210098, P. R. China) \\ (2: College of Environment, Hohai University, Nanjing 210098, P. R. China)
}

\begin{abstract}
In order to understand eutrophication levels and characteristics of phytoplankton distribution in Changtan Reservoir in Meizhou City, Guangdong Province, and provide scientific basis for controlling of algae bloom, physico-chemical data, phytoplankton species and densities were determined from October 2011 to July 2012 from 10 sampling sites in Changtan Reservoir. The status of water pollution was evaluated based on trophic level index, Shannon-Wiener index, and analysis characteristics of phytoplankton distribution in Changtan Reservoir. The results showed that the Changtan Reservoir was at middle eutrophication level characterized in April, October and December, and high eutrophication level with downward trend from upstream to the reservoir in July. A total of 16 phytoplankton species have been identified, which belong to 4 phyla and 11 families, among which cyanobacteria and green alga were predominant with obvious seasonal succession. The density of phytoplankton ranged from high to low in order of the following months: July > April > October $>$ December. Shannon-Wiener index value analysis showed that water pollution level was medium for the reservoir water body, and light in the upstream and reservoir catchment area (except July) ; this is consistent with the trophic level index values. The pollution source survey showed that nitrogen and phosphorus were the main pollutant indices of Changtan Reservoir, and mainly from livestock breeding wastewater.
\end{abstract}

Keywords: Phytoplankton; eutrophication; Changtan Reservoir

* 水利部公益性专项项目 (201101020)、国家水体污染控制与治理科技重大专项项目 (2012ZX07101-008) 和江苏省 杰出青年基金项目 (BX2012037) 联合资助. 2012-12-25 收稿;2013-03-21 收修改稿. 王超, 男, 1958 年生,教 授;E-mail:cwang@hhu.edu.cn.

** 通信作者;E-mail:pfwang2005@ hhu. edu.cn. 
水库在我国工农业生产和人民生活中起着十分重要的作用. 近年来, 由于环境污染, 大量营养元素流人 水库, 特别是氮、磷的化合物, 改变了浮游植物群落结构, 阻碍了群落之间物质和能量的交换 ${ }^{\left[{ }^{1]}\right.}$, 加速了水体 富营养化并导致水质恶化 ${ }^{[2-3]}$.

浮游植物是淡水生态系统中重要的初级生产者, 在淡水生态系统的能量流动、物质循环和信息传递中 起着至关重要的作用 ${ }^{[4-5]}$. 由于水库存在明显的人为调节因素, 使其生态系统有别于自然湖泊. 浮游植物种 类的组成、分布不但受到光照、水温和水体中氮、磷及微量元素含量的影响, 也与水体的流动性、底泥、微生 物等环境因素相关,体现出较大的个体差异 ${ }^{[6-7]}$.

长潭水库位于广东省梅州市蕉岭县长潭镇, 是一座以发电为主兼有防洪、灌溉、供水、旅游等功能的大 型水库. 长潭水库作为饮用水源一级保护区, 其水质的好坏直接关系着梅州市人民健康、经济发展和社会稳 定. 根据当地环境监测部门监测报告, 长潭水库一年中发生数次蓝藻水华, 因此, 长潭水库富营养化控制与 蓝藻水华治理具有重要意义.

\section{1 材料与方法}

\section{1 水库概况}

长潭水库位于广州省与福建省交界处, 气候温和, 全年平均水温 $24^{\circ} \mathrm{C}$, 集水面积为 $1990 \mathrm{~km}^{2}$, 设计洪水 位为 $151.5 \mathrm{~m}$, 总库容为 $1.7 \times 10^{8} \mathrm{~m}^{3}$, 设计正常高水位为 $148.0 \mathrm{~m}$, 汛期防洪限制水位为 $144.0 \mathrm{~m}$, 死水位为 $136.5 \mathrm{~m}$,多年平均流量 $55.80 \mathrm{~m}^{3} / \mathrm{s}$, 属季调节水库.

\section{2 采样点位置及采样频率}

2011 年 10 月至 2012 年 7 月对长潭水库进行了 4 次现场调查以及系统样品采集, 具体时间为 2011 年 10 月、 2011 年 12 月、 2012 年 4 月和 2012 年 7 月. 在长兴电站至长潭电站沿线设置了 10 个采样点, 其中调查 区上游为 $1^{\#} \sim 3^{\#}$, 中游为 $4^{\#} \sim 6^{\#}$, 库区为 $7^{\#} \sim 10^{\#}$. 采样点用 GPS 定位, 位置如图 1 所示.

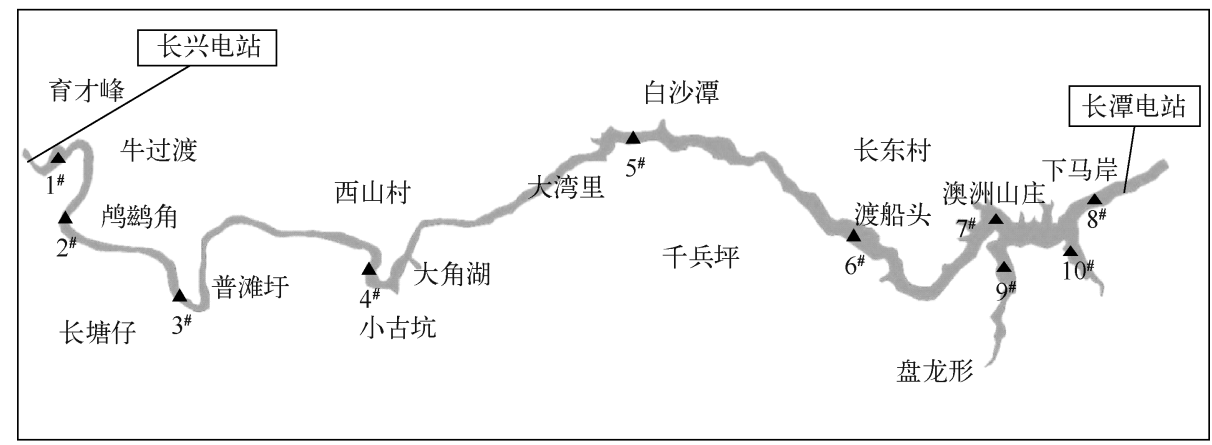

图 1 采样点位分布

Fig. 1 Distribution of sampling sites

\section{3 样品采集、处理与分析}

1.3.1 水质分析 监测指标包括温度、透明度、 $\mathrm{pH}$ 、 DO 、总氮 (TN) 、总磷 $(\mathrm{TP}) 、$ 、叶绿素 $\mathrm{a}(\mathrm{Chl} . \mathrm{a})$, 现场记录温 度、透明度、 $\mathrm{pH}$ 值、溶解氧 ( DO). 用 YSI 多参数水质检测仪测定水温、溶解氧, 透明度使用塞式盘测定, $\mathrm{pH}$ 采 用便携式水质分析仪测定. 样品中加人 $\mathrm{H}_{2} \mathrm{SO}_{4}$ 酸化保存, 并用聚乙烯瓶运回实验室立刻进行分析, 其他指标 按照《水和废水监测分析方法》测定 ${ }^{[8]}$.

1.3.2 藻类分析 定性分析: 浮游植物采样依照《淡水浮游生物研究方法》 ${ }^{[9]}$ 及湖泊富营养化调查规 范 ${ }^{[10]}$ 中的方法. 用 $25^{\#}$ 浮游生物网在水面以下或 $0.5 \mathrm{~m}$ 处以 $20 \sim 30 \mathrm{~cm} / \mathrm{s}$ 的速度作 $\infty$ 形来回缓慢拖动约 3 min. 按照 1000: 15 的体积比加人鲁哥试剂固定, 待镜检 ${ }^{[1-12]}$. 定量分析: 取表层以下 $0.5 \mathrm{~m}$ 处水样 $1000 \mathrm{ml}$, 加人 $15 \mathrm{ml}$ 鲁哥试剂固定, 在实验室中把样品摇匀并静置 $48 \mathrm{~h}$ 后取出 $30 \mathrm{ml}$ 沉淀浓缩液, 使用 $0.1 \mathrm{ml}$ 计数框 作定量计数 ${ }^{[9,11-12]}$. 
1.3.3 评价方法 营养状态指数 $(T L I)$ 法: 使用 Carlson 方法评价 ${ }^{[10]}$, 采用 $0 \sim 100$ 的连续数字对长潭水库营 养状态分级, $T L I<30$ 为贫营养, $30 \sim 50$ 为中营养, $50 \sim 100$ 为富营养. 在同一营养状态下, 指数值越高, 其营 养程度越重.

$$
\begin{gathered}
\operatorname{TLI}(\Sigma)=\sum_{j=1}^{m} W_{j} \cdot \operatorname{TLI}(j) \\
W_{j}=r_{i j}^{2} / \sum_{j=1}^{m} r_{i j}^{2}
\end{gathered}
$$

式中, $T L I\left(\sum\right)$ 为综合营养状态指数, $W_{j}$ 为第 $j$ 种参数的营养状态指数, $T L I(j)$ 为第 $j$ 种参数的营养状态指数, $r_{i j}^{2}$ 为以 Chl. a 为基准参数, 第 $j$ 种参数与基准参数 Chl. $\mathrm{a}$ 的相关系数, $m$ 为评价参数的个数. 富营养化状态评 价指标选用 Chl. a SD 、TP 三项参数, 计算公式分别为:

$$
\begin{gathered}
T L I(\text { Chl. a })=10(2.5+1.086 \ln \text { Chl. a }) \\
T L I(\mathrm{SD})=10(5.118-1.94 \ln \mathrm{SD}) \\
T L I(\mathrm{TP})=10(9.436+1.624 \ln \mathrm{TP})
\end{gathered}
$$

式中, Chl. a 的单位为 $\mu \mathrm{g} / \mathrm{L}, \mathrm{SD}$ 的单位为 $\mathrm{m}$, TP 的单位为 $\mathrm{mg} / \mathrm{L}$.

应用 Shannon-Wiener 多样性指数 $(H)$ 法进行生物多样性指数评价,计算公式为:

$$
H=-\sum_{i=1}^{S}\left(n_{i} / N\right) \ln \left(n_{j} / N\right)
$$

式中, $S$ 为藻类种类数, $n_{i}$ 为某种藻类的个体数, $N$ 为各种藻类的总个体数.

\section{4 数据采集和处理}

所有数据采用 3 个平行样,用 SPSS 19.0 统计学软件对水质理化数据和藻类数据进行分析,并计算营养 状态指数 $T L I$ 值和多样性指数 $H$ 值.

\section{2 结果与分析}

\section{1 富营养化状态分析}

长潭水库富营养化指数 $T L I(\mathrm{Chl} . \mathrm{a}) 7$ 月高于其他月份且大于 50 , 属于富营养级,4 月库区略高于中游 和上游, 但差异不明显, 10 月和 12 月富营养化状态较低,处于中营养级. $T L I(S D)$ 呈现自上游至库区逐渐 下降的趋势, 上游处于富营养级, 中游除 12 月处于中营养级外, 其他月份为富营养级, 库区 7 月份 $T L I(\mathrm{SD})$ 高于其他月份, 处于富营养级. $T L I(\mathrm{TP})$ 上游高于 50 , 属于富营养级, 中游和库区除 12 月处于富 营养级, 其他月份属于中营养级. 综合营养状态指数 $T L I(\Sigma) 10$ 月和 12 月处于中营养级, 4 月库区属于富 营养级, 上游和中游属于中营养级, 7 月份各采样点 $T L I(\Sigma)$ 大于 50 , 属于富营养级, 其中库区和中游富营 养化程度较高 (图 2).

广东省有大型水库 29 个, 中型水库 274 个, 小型水库 6400 多个, 总库容 $398 \times 10^{8} \mathrm{~m}^{3}$ (1993 年统计数 据 $\left.{ }^{1}\right)$, 总库容在全国列第 4 位. 江涛等 ${ }^{[13]}$ 于 2005 年对广东省 132 座水库进行营养状态评价, 其中中营养型 水库占多数, 为 111 座, 并发现水库的营养程度有一定的季节变化. 长潭水库总库容为 $1.7 \times 10^{8} \mathrm{~m}^{3}$, 属大型 水库 ${ }^{[14]}$, 富营养化程度相对较低, 水库多数时间处于中营养状态. 然而广东省水库处在热带亚热带地区, 受 夏季风影响的强降雨成为水体动力条件的主要控制因素, 导致夏季水库富营养状态加重 ${ }^{[15]}$.

\section{2 浮游植物的群落结构}

2. 2.1 浮游植物群落组成 共检测到浮游植物 4 门 11 科 16 属, 其中蓝藻门 4 科 9 属, 绿藻门 5 科 5 属,

(1) 广东省水中长期供求计划编制组编, 1996 . 

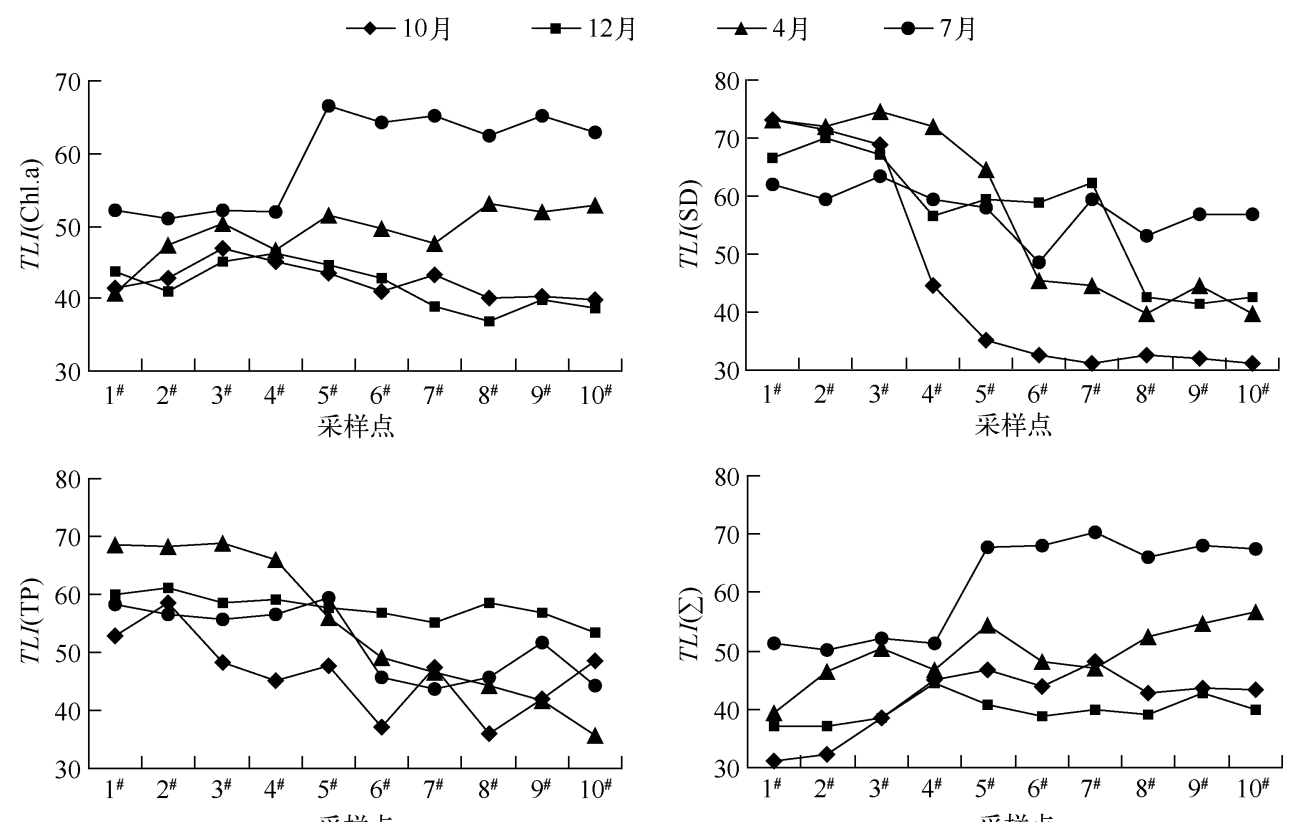

采样点

采样点

图 2 长潭水库各采样点营养状态指数

Fig. 2 Trophic level index of sampling sites in Changtan Reservoir

硅藻门 1 科 1 属, 黄藻门 1 科 1 属. 较为常见的有蓝藻门的微囊藻、色球藻、束丝藻、鞘丝藻, 绿藻门的 栅藻、小球藻、鼓藻, 硅藻门的直链藻 (表 1 ). 长潭水库检出的浮游植物大多为富营养化水体常见 种类.

表 1 长潭水库浮游植物群落组成

Tab. 1 Composition of phytoplankton in Changtan Reservoir

\begin{tabular}{lll}
\hline 门名 & 科名 & 属名 \\
\hline 蓝藻门 Cyanophyta & 色球藻科 Chrococcaceae & 微囊藻属 Microcystis \\
& & 色球藻属 Chroococcus \\
& & 束球藻属 Gomphosphaeria \\
& 腔球藻属 Coelosphaerium \\
& 念珠藻科 Nostocaceae & 念珠藻属 Nostoc \\
& & 束丝藻属 Aphanizomenon \\
& 微毛藻科 Microchaetaceae & 柱孢藻属 Cylindrospermopsis \\
& & 微毛藻属 Nostocales \\
& 颤藻科 Oscillatoriaceae & 鞘丝藻属 Lyngbya \\
& 栅藻科 Scenedesmacea & 栅藻属 Scenedesmus \\
& 刚毛藻科 Cladophora Chloprophyta & 刚毛藻属 Cladophora \\
& 小球藻科 Chlorellaceae & 小球藻属 Chlorella \\
& 丝藻科 Ultrichaceae & 丝藻属 Ulothrix \\
& 鼓藻科 Desmidiaceae & 鼓藻属 Cosmarium \\
& 直链藻科 Melosiraceae & 直链藻属 Melosira \\
硅藻门 Bacillariophyta & 黄丝藻科 Tribonemataceae & 黄丝藻属 Tribonema \\
黄藻门Xanthophyceae &
\end{tabular}

2.2 .2 浮游植物种类演替 调查期间, 长潭水库蓝藻门种类数最多, 绿藻门次之, 硅藻门和黄藻门最少, 可认 为长潭水库浮游植物群落为蓝藻一绿藻型. 7 月蓝藻门种类数高于其他季节, 共检出蓝藻门 10 属 (图 3 ). 4 、7 
和 10 月优势属为蓝藻门的微囊藻属和绿藻门 的刚毛藻属; 12 月份优势属有蓝藻门的柱孢藻 属、绿藻门的栅藻属和硅藻门的直链藻属.

不同营养状态的水体中存在不同的生物 种类,特别是在优势种方面差异明显. 在广东 富营养程度较高的水库中,徐宁等 ${ }^{[16]}$ 对浮游植 物调查发现,水库浮游植物的种类组成以绿藻 为主,其次是硅藻和蓝藻, 其他藻类很少出现, 大部分水库浮游植物优势种为蓝藻. 而对处于 贫营养水平的广东南水水库浮游植物调查中 发现, 硅藻门种类最多, 其次为蓝藻门,优势种 为硅藻 ${ }^{[17]}$. 长潭水库总体处于中营养状态, 浮 游植物组成以蓝藻为主, 绿藻次之.

\section{3 浮游植物总量及分布特征}

2.3 .1 浮游植物总量分布 长潭水库各点位澡 类总丰度变化范围为 $29 \times 10^{5} \sim 1760 \times 10^{5} \mathrm{cells} / \mathrm{L}$, 其中, 7 月最高, 为 $1760 \times 10^{5} \mathrm{cells} / \mathrm{L}$, 其次分别 为 4 月 $\left(240 \times 10^{5} \mathrm{cells} / \mathrm{L}\right) 、 10$ 月 $(46 \times$ $10^{5}$ cells $\left./ \mathrm{L}\right), 12$ 月最低. 从空间分布来看, 7 月 人库河流中游 $5^{\#}$ 采样点浮游植物丰度最高, 达 到 $330 \times 10^{5}$ cells $/ \mathrm{L}$, 上游较低, 均低于 $100 \times$ $10^{5}$ cells $/ \mathrm{L}$ (图 4). 由于上游长兴电站的调控导 致上游流速较大, 在一定程度上抑制了藻类生 长; 而 $5^{\#}$ 点位于长兴电站与长潭电站中间, 水流 缓慢, 营养盐容易滞留于水体中, 当夏季温度和 光照满足藻类生长时, 将会导致藻类大量 繁殖 ${ }^{[18-19]}$.

广东省水库受亚热带季风气候影响, 浮游 植物丰度受水温的季节变化影响较小, 更大程 度上与水文的季节变化性相关 ${ }^{[20]}$. 李莹等 ${ }^{[21]}$ 调 查发现水库营养盐、悬浮颗粒物和水力滞留时 间与流域水文循环密切相关. 何国全等 ${ }^{[22]}$ 对广 东飞来峡水库调查发现, 降水增加有利于人库 营养盐水平的提高, 促进浮游植物的生长和生 物量的增加, 但水力滞留时间会随水库出库流 量的增加而下降.

\section{3 .2 浮游植物门类季节变化特征 长潭水库} 蓝藻门、绿藻门丰度所占藻类总丰度百分比最 多(图 5), 两者丰度所占比例高于 $80 \%, 7$ 月份 达到 $96 \%$, 硅藻门丰度 10 月和 12 月份别占 $18 \%$ 和 $17 \%, 4$ 月降低到 10\%,7 月最低为 $3 \%$, 黄藻门丰度最低, 占 $0.6 \% \sim 3.0 \%$. 这主要因为 蓝藻、绿藻适应性广泛, 对高光照和高温度适应能力最强, 当夏季光线充足、水温较高, 蓝藻、绿藻大量繁殖, 抑制了硅藻和黄藻的生长. 而正常情况下, 藻类相互竞争与演替, 使群落结构保持动态平衡.

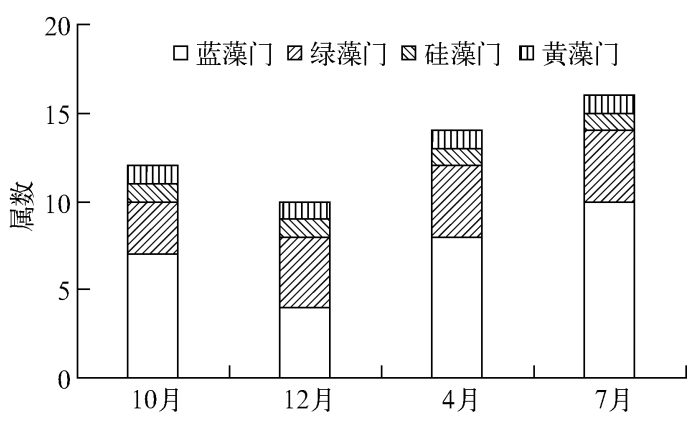

图 3 长潭水库浮游植物属数季节演替

Fig. 3 Seasonal succession of phytoplankton in Changtan Reservoir

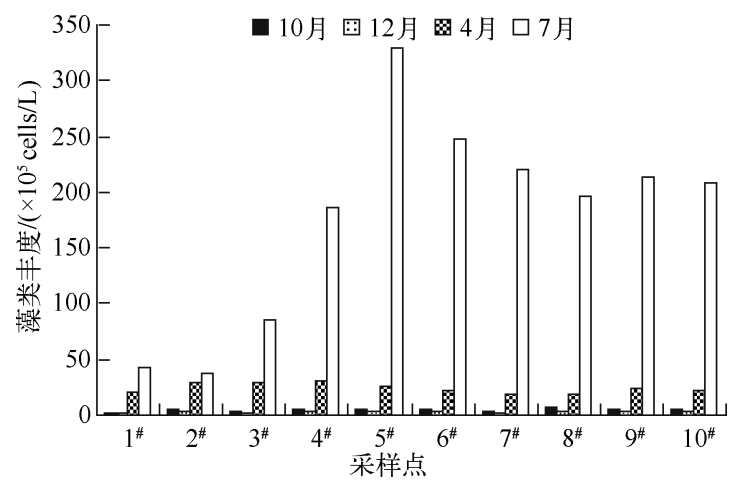

图 4 长潭水库浮游植物丰度变化

Fig. 4 Density changes of phytoplankton in Changtan Reservoir

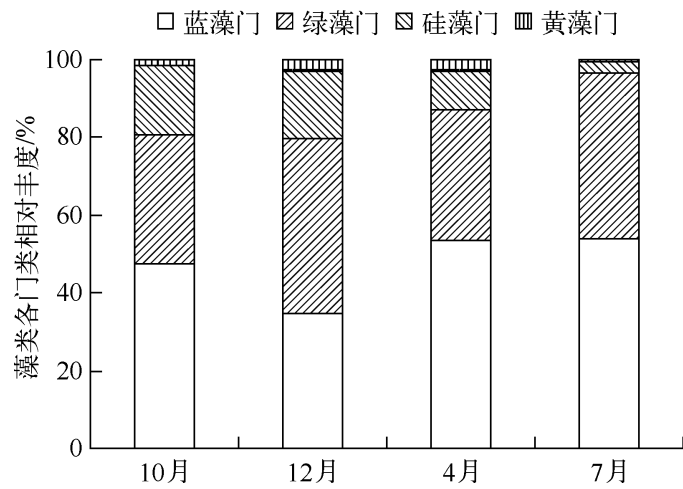

图 5 长潭水库浮游植物各门类丰度组成

Fig. 5 Density composition of phytoplankton in Changtan Reservoir 


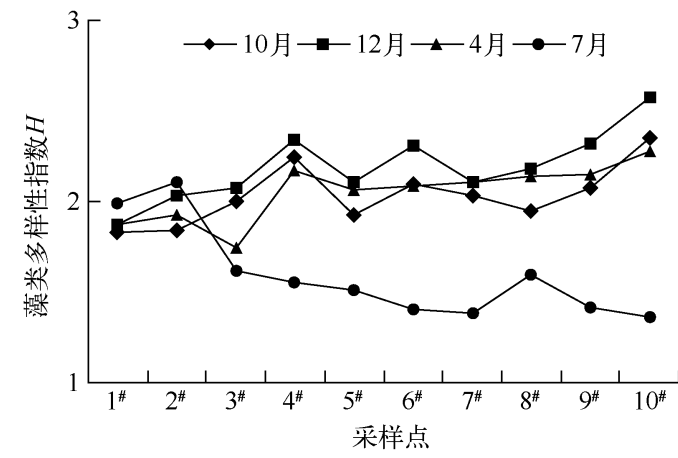

图 6 长潭水库浮游植物多样性指数 $H$

Fig. 6 Shannon-Wiener index of phytoplankton in Changtan Reservoir

\section{4 藻类多样性指数}

多样性指数大小反映水体水质状况, 多样性指 数值愈大表明水质愈好; 反之多样性指数值愈小表 明水质污染愈重. 根据不同 $H$ 值对长潭水库富营养 化分级, $H>3$ 为清洁; $2<H \leqslant 3$ 为轻度污染; $1<H \leqslant$ 2 为中度污染; $0<H \leqslant 1$ 为重度污染. 调查结果表明 (图 6), 长潭水库上游多样性指数 $H$ 值维持在 $1.6 \sim$ 2.0 之间, 只有 12 月 $2^{\#} 、 3^{\#}$ 采样点和 7 月 $2^{\#}$ 采样点 $H$ 值略高于 2.0 , 但均不超过 2.1 , 可认为上游处于中 度污染; 中游和库区在 7 月份污染较重, 多样性指数 $H$ 值低于 1.6 , 属于中度污染且污染程度高于上游, 这主要是由于 7 月浮游植物丰度大、优势种显著, 其 余月份中游和库区处于轻度污染. 藻类多样性指数 与综合营养状态指数 $T L I\left(\sum\right)$ 在 7 月份呈现出

库区 > 中游 > 上游的营养状态. 其余月份 $H$ 值与 $T L I\left(\sum\right)$ 空间变化趋势相反, 但都处于较低的中营养状态.

\section{5 污染成因调查}

长潭水库水质分析表明, 长潭水库水质整体较差, 特别是上游污染严重, 这同水流流向和污染来源有 关. 长潭水库的氮、磷污染总负荷分别为 4324.18 和 $65.53 \mathrm{t} / \mathrm{a}$. 其中长兴电站上游携带的氮、磷污染负荷分 别为 2563.2 和 $40.05 \mathrm{t} / \mathrm{a}$, 分别占水库污染总负荷的 $59.3 \%$ 和 $61.1 \%$, 成为水库污染物的主要来源. 通过对 长潭水库污染源的调查, 水库水体现状主要污染源由农村生活面源、农田面源、禽畜养殖、船舶 4 部分组成, 其中船舶污染主要为石油类污染. 长潭水库全年共接受氮、磷负荷分别为 $1246.09 、 244.00 \mathrm{t}$. 从各类污染源 的贡献率看, 禽畜养殖的污染贡献率最大, 禽畜养殖氮的贡献率达到 $47.58 \%$, 磷的贡献率占主导地位, 所占 比例达到79.22\% (表 2).

表 2 长潭水库人库污染源的统计分析 *

Tab. 2 Statistical analysis of input pollution sources in Changtan Reservoir

\begin{tabular}{cccccc}
\hline \multirow{2}{*}{ 污染类别 } & \multicolumn{3}{c}{ 氮 } & & \multicolumn{2}{c}{ 磷 } \\
\cline { 2 - 3 } \cline { 6 - 6 } & 负荷 $/ \mathrm{t}$ & 污染贡献率/\% & & 负荷/ $\mathrm{t}$ & 污染贡献率/\% \\
\hline 农村生活面源 & 123.06 & 9.88 & & 15.17 & 6.22 \\
农田面源 & 530.13 & 42.54 & & 34.53 & 14.15 \\
禽畜养殖 & 592.9 & 47.58 & & 193.3 & 79.22 \\
合计 & 1246.09 & 100 & & 244.00 & 100 \\
\hline
\end{tabular}

* 船舶污染主要指石油类的污染,暂不统计氮、磷数据.

根据江涛等 ${ }^{[13]}$ 对广东省水库营养化原因分析, 广东省水库水质污染和富营养化的主要根源有: 城市化 带来的污废水排放、农业面源污染、水库泥沙淤积、水库蓄水量减少. 长潭水库污染源主要为畜禽养殖. 畜禽 粪便的营养盐成分相对较稳定, 营养盐主要以地表径流方式输人水库, 造成营养盐输人量因地表径流的季 节变化而产生季节差异, 从而导致水库丰水期富营养程度高于枯水期. 因此, 为改善和保持长潭水库水体水 质, 必须对各类污染源加强综合管理, 对禽畜养殖制定严格的减排和限排措施.

\section{3 结论}

1) 长潭水库富营养化较重,4 次调查中,4、10 和 12 月均处于中营养状态, 7 月营养状态指数明显增加, 调查区域内处于富营养状态, 其中库区富营养化程度最重.

2) 调查期间共检出浮游植物 4 门 11 科 16 属, 7 月份检出的浮游植物种类最多, 水库浮游植物群落为蓝 藻一绿藻型. 浮游植物丰度季节变化明显, 浮游植物丰度为 7 月 $>4$ 月 $>10$ 月 $>12$ 月. 各季节蓝藻门、绿藻门 
丰度所占藻类总丰度百分比最高, 两者所占比例超过 $80 \%$.

3) 长潭水库上游藻类多样性指数值较低, 水体污染水平为中度污染, 中游和库区 ( 除 7 月) 为轻度污 染; 7 月藻类多样性指数值最低, 水库污染严重, 为中度污染, 这与综合营养指数 TLI $\left(\sum\right)$ 结果一致.

4) 长潭水库主要为氮、磷污染,污染源主要为禽畜养殖; 为改善和保持长潭水库水体水质,必须对各类 污染源加强综合管理,对禽畜养殖制定严格的减排和限排措施.

\section{4 参考文献}

[ 1 ] Vincon-Leite B, Tassin B, Druart JC. Phytoplankton variability in Lake Bourget: phytoplankton dynamics and meteorology. Lakes \& Reservoirs: Research \& Management, 2002,7(2) :93-102.

[ 2 ] Aguiar VMC, Neto JAB, Rangel CM. Eutrophication and hypoxia in four streams discharging in Guanabara Bay, RJ, Brazil, a case study. Marine Pollution Bulletin, 2011,62 :1915-1919.

[ 3 ] 陈水勇,吴振明,俞伟波. 水体富营养化的形成、危害和影响. 环境科学与技术,1999,(2):11-15.

[ 4 ] 李敦海,李根宝, 王高鸿等. 水华蓝藻生物质对沉水植物五刺金鱼藻生长的影响. 水生态学报, 2007,31 (5): 689-692.

[ 5 ] 张 婷, 宋立荣. 铜绿微囊藻 (Microcystis aeruginosa) 与三种丝状蓝藻间的相互作用. 湖泊科学, 2006, 18 (2): 150-156.

[ 6 ] Figueredo CC, Giani A. Seasonal variation in the diversity and species richness of phytoplankton in a tropical eutrophic reservoir. Hydrobiologia, $2001, \mathbf{4 4 5}: 165-174$.

[ 7 ] 林 娴,陈棉润,韩博平. 横岗水库浮游植物种类组成与时空分布. 生态科学,2007,26(4):303-310.

[ 8 ] 国家环境保护总局《水和废水监测分析方法》编委会. 水和废水监测分析方法:第 4 版. 北京: 中国环境科学出版 社,2002.

[9] 章宗涉,黄祥飞. 淡水浮游生物研究方法. 北京: 科学出版社, 1991.

[10］金相灿,屠清瑛. 湖泊富养化调查规范:第 2 版. 北京:中国环境科学出版社, 1990 .

[11] 胡鸿钧,李尧英,魏印心等. 中国淡水藻类. 上海:上海科学出版社,1979.

[12］韩茂森. 淡水生物图谱. 北京:农业出版社,1978.

[13] 江 涛,刘祖发,陈晓宏等.广东省水库富营养化评价. 湖泊科学,2005,17(4):378-382.

[14] 林秋奇,韩博平. 水库生态系统特征研究及其在水库水质管理中的应用. 生态学报,2001,21(6) :1034-1040.

[15] 张华俊,李秋华,韩博平. 南亚热带典型调水型水库一广东大镜山水库的富营养化特征分析. 湖泊科学, 2010,22 (2) :291-299.

[16] 徐 宁,段瞬山,林秋奇等. 广东大中型供水水库的氮污染与富营养化分析. 生态学杂志,2004,23(3):63-67.

[17] 岳 强,黄 成,史元康等. 广东南水水库富营养化与浮游植物群落动态. 环境科学与技术, 2012,35(8):112-116.

[18］ 孔繁翔,高 光. 大型浅水富营养化湖泊中蓝藻水华形成机理的思考. 生态学报,2005,25(3):589-595.

[19] Philips EJ, Cichra M, Havens K et al. Relationships between phytoplankton dynamics and the availability of light and nutrients in a shallow sub-tropical lake. Journal of Plankton Research, 1997,19:319-342.

[20] Figueredo CC, Giani A. Seasonal variation in the diversity and species richness of phytoplankton in a tropical eutrophic reservoir. Hydrobiologia, 2001,445 : 165-174.

[21] 李 莹, 肖利娟, 林秋奇等.一座新建水库一一广东剑潭水库浮游植物动态特征. 湖泊科学, 2010,22(2):227-234.

[22] 何国全,雷腊梅, 韩博平. 南亚热带河流型水库浮游植物群落的季节变化: 以广东飞来峡水库为例. 热带亚热带植 物学报,2006,14(3) : 183-189. 